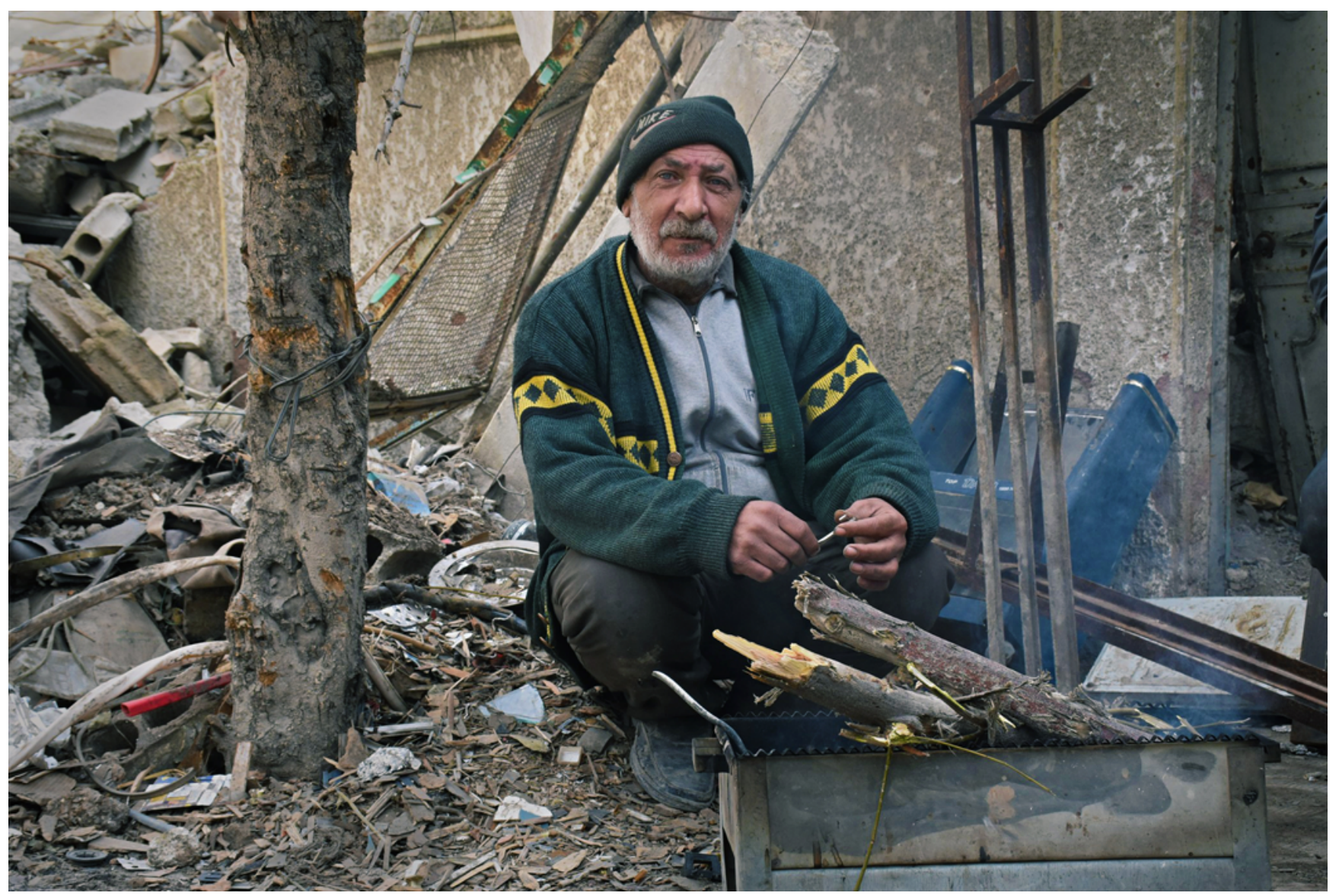

Mohammad, 66, sits in front of his home in Eastern Ghouta. He and his family survived the five-year battle but now face threats of a different kind. Photo: Dania Kareh/Oxfam.

\title{
AID IN LIMBO
}

\section{Why Syrians deserve support to rebuild their lives}

The crisis in Syria is entering its ninth year. With a reduction in active violence, there is a need to consider how the aid response is best meeting the needs of conflict-affected Syrians. Yet the political stance of donor governments, combined with access restrictions in Syria, is preventing humanitarian actors from supporting Syrians with sustainable access to basic services and livelihoods. This paper explores the changes that are needed to adapt the response to deliver the support Syrians themselves want.
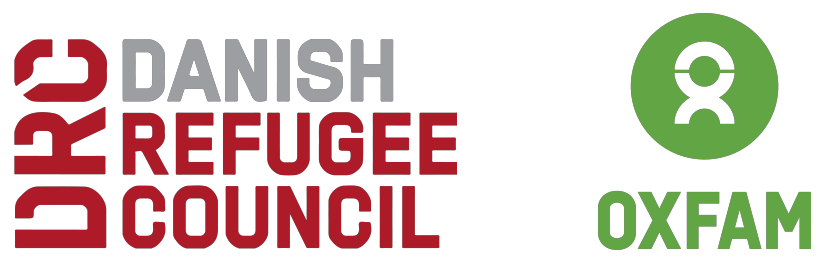


\section{SUMMARY}

All aid delivery in Syria raises several complex issues and challenges, and this paper sets out these issues, focusing on early recovery programming in government-controlled Syria. All those involved in delivering the humanitarian response need to begin thinking and interacting differently to ensure that those who are in need receive the support they identify as most helpful to them.

Decision making will need to be centred around the preferences of ordinary Syrians, including the needs, rights and aspirations of all Syrians for the future, while remaining rooted in humanitarian principles. The Government of Syria will need to increase access for humanitarian actors and donors will need to fund programming that supports vulnerable communities to access basic services and livelihoods, based on needs and not areas of control.

After eight years of crisis in Syria, millions of women, men and children continue to find themselves in desperate need of humanitarian assistance. 11.7 million people in Syria remain in need, with 5 million in acute need. 7.2 million of these people in need live in government-controlled areas. ${ }^{1} \mathrm{~A}$ 'Whole of Syria' approach will continue to be required to reach everyone in need.

But as conflict patterns change, hundreds of thousands of people are no longer living in communities experiencing active, widespread armed conflict, ${ }^{2}$ resulting in changing humanitarian needs.

Humanitarian challenges can only be tackled appropriately if people are at the heart of the response, their rights are respected and their participation is mainstreamed. However, sustained, unhindered access remains a significant challenge to operations in government-controlled Syria. Hurdles including long approvals processes; restrictions on independent needs assessments; delays to approvals for programmes, activities and travel; and visa restrictions all impact on organizations' abilities to best support people's needs. The Government of Syria must increase access for humanitarian organizations to populations in need.

Civic space inside Syria is heavily restricted, although several Syrian organizations already deliver much-needed aid. Yet the Government of Syria and humanitarian actors must work together to find ways to ensure that civilians receiving aid can direct the type of assistance they receive, provide independent feedback on the quality of assistance and inform programming changes to better meet their needs.

And because a principled humanitarian response is only possible when gender and women's perspectives are incorporated at all stages, specific attention must be paid to creating spaces for women to engage with the planning and monitoring of interventions - bearing in mind cultural practices.

Time and time again, Syrians say that the type of support they want is the restoration of basic infrastructure, rehabilitation, and support for them and their families to become more self-reliant through support for livelihoods. 
Despite this, funding and implementing early recovery programmes in government-controlled Syria is becoming more and more difficult. Many donors have been clear that they are unwilling to discuss reconstruction inside Syria until some form of political transition is firmly under way, and are making incorrect links between reconstruction and early recovery humanitarian assistance. There are growing concerns that political strategies and slogans are overshadowing necessary, technical discussions on transitioning from solely emergency responses to dignified, sustainable, cost-effective support for fragile communities.

In other contexts, reconstruction has had a tendency to focus on the state and its capacity, not on people. By contrast, early recovery - like all humanitarian assistance - is needs-based, gender-responsive, targets vulnerable communities, is based on humanitarian principles, has a clear focus on protection and is implemented in a conflict-sensitive manner.

The concerns around reconstruction in Syria are valid - but they do not mean there should be no early recovery or support for community-level resilience work, including for populations living in government-controlled areas of the country.

In what is a protection crisis, increasing access to basic services, helping children back to school and providing more women with livelihoods opportunities can deliver immediate protection benefits, including reducing risks of sexual and gender-based violence (SGBV), and reducing the use of negative coping strategies - for example child labour and early marriage. It also gives people greater agency in their own lives and affords them dignity - something humanitarians aim to put at the heart of all responses.

Issues related to the impact of sanctions and bank de-risking must also be addressed, so that organizations can support women, men and children with the most effective and dignified responses.

Humanitarian organizations must be clear about the principles that underpin their work: adherence to the humanitarian standards of impartiality, independence and operational neutrality; gender responsiveness; conflict sensitivity; and the centrality of protection (in line with Inter Agency Standing Committee (IASC) standards).

Supporting communities to begin to recover will be a complex process. This work will require the Syrian government to provide sustainable and timely humanitarian access, and for all actors to stop politicizing aid inside Syria. Donors should invest in sustainable, cost-effective approaches, not simply avoid supporting basic services, and instead focus all their efforts on people affected by conflict and their needs. 


\section{RECOMMENDATIONS}

\section{To donors}

- Commit to funding all activities identified as part of the HRP, including the third pillar on early recovery and livelihoods support on the basis of need, regardless of who is in control.

- Increase longer-term, flexible humanitarian funding (at least 24 months), supporting organizations working from Damascus to implement communitydesigned programming and negotiate the approvals process, recognizing that bureaucratic hurdles can prevent the immediate start of projects.

- Continue to support programmes that repair existing infrastructure to increase civilian access to basic services, social service delivery and sector management capacity, with a focus on services that provide an immediate protection benefit. Programmes should be targeted based on needs and vulnerability.

- Support individuals to resume or strengthen food production activities and capabilities to increase household food availability and enable income generation.

- Support programmes for conflict-affected Syrians to access livelihoods, including vocational training programmes and grants to small- and mediumsized businesses, and the rehabilitation of local markets and value chains for new business opportunities. Programmes should be gender-responsive and support women entering new sections of the economy, be conducted in line with a market and value-chain analysis, and target people according to need and vulnerability.

- Require and provide support for humanitarian actors to produce coherent conflict-sensitivity strategies to underpin collective early recovery and resilience strategies for areas under government control, in addition to individual projects.

- Support Damascus-based organizations to develop operational procedures and common standards for operations out of the hub, including agreed modalities for more effective risk sharing between humanitarian organizations and donors.

- Ensure that donors follow standards of principled engagement inside Syria.

- Ensure all programmes adhere to Core Humanitarian Standards.

\section{To the Government of Syria}

- Reduce bureaucracy around approvals, including for needs assessments and programme monitoring, and to increase transparency and reduce delays in approval processes.

- Ensure free movement for all humanitarian staff to work regularly and freely in areas of need.

- Ensure any and all military acts do not cause harm to civilians or civilian infrastructure, and adhere to International Humanitarian Law. 
- Allow more organizations to work from Damascus, enabling the humanitarian response to reach more people in need.

- Ensure that Syrians, including Syrian women, are able to access civil and legal documentation that protects their housing, land and property rights, and ensure that support can be provided to populations without documentation, enabling humanitarian actors to develop programmes around stable populations.

- Facilitate visas for permanent and temporary expert international staff who can develop and support effective early recovery programming, and facilitate their greater movement across Syria.

- Enable humanitarian actors to effectively deliver programmes in all three pillars of the HRP, ensuring that programmes can be gender-responsive, follow IASC Protection Principles and can be delivered in line with Core Humanitarian Standards.

\section{To all parties to the conflict}

- Ensure that any and all military acts do not deliberately cause harm to civilians or civilian infrastructure, and adhere to International Humanitarian Law.

- Facilitate unimpeded humanitarian access to populations in need.

\section{To the United Nations}

- Take a leadership role in advocating for early recovery programmes that increase access to basic services and build resilience, while ensuring emergency life-saving needs are also met.

- Increase dialogue with donors and INGOs to share conflict and risk analyses, and to ensure a collaborative approach to respond to humanitarian needs in Syria.

- Continue the discussion with donors around operational procedures and common standards for operations out of the Damascus hub, including agreed modalities for more effective risk sharing between humanitarian organizations and donors.

- Work between UN agencies and with INGOs in Damascus to improve and share conflict and risk analysis in programme design, and set out conflictsensitivity plans for all programmes conducted, whether or not they are part of the HRP.

- Ensure the centrality of protection in all programmes, including a focus on the reduction of gender-based violence, and that programmes meet Core Humanitarian Standards.

\section{To International NGOs working from Damascus}

- Improve and share conflict and risk analysis in programme design, ensuring that programmes Do No Harm and enhance protection of civilians.

- Ensure that programmes are designed bottom-up, with the involvement of the local community (including local government) to ensure that they meet the 
needs identified by conflict-affected populations, and increase accountability at the local level.

- When delivering early recovery and resilience programming, ensure that it does not reinforce a reduction in housing, land and property rights, and supports people's protection.

- Programmes should be designed through a gender lens, and livelihoods programmes should work with men to ensure that women can take up economic opportunities in all areas of the labour market, following a valuechain analysis and market assessment.

- Increase dialogue with local stakeholders to ensure that they are aware of humanitarian principles and have ownership over wider access to services. Undertake planning at an area-wide level.

- Ensure the centrality of protection in all programmes, including a focus on the reduction of gender-based violence. 


\section{INTRODUCTION}

Eight years of war have left huge swathes of Syria in ruins. Over the course of 2018, the Government of Syria regained significant territory in the south of the country including rural Damascus, Eastern Ghouta and Dar'a, leaving only areas in the north-east and north-west of the country under the control of non-state actors. This means that for the first time in eight years, hundreds of thousands of people are no longer living in places experiencing active, widespread armed conflict, ${ }^{3}$ resulting in changing needs for the women, men and children in these areas.

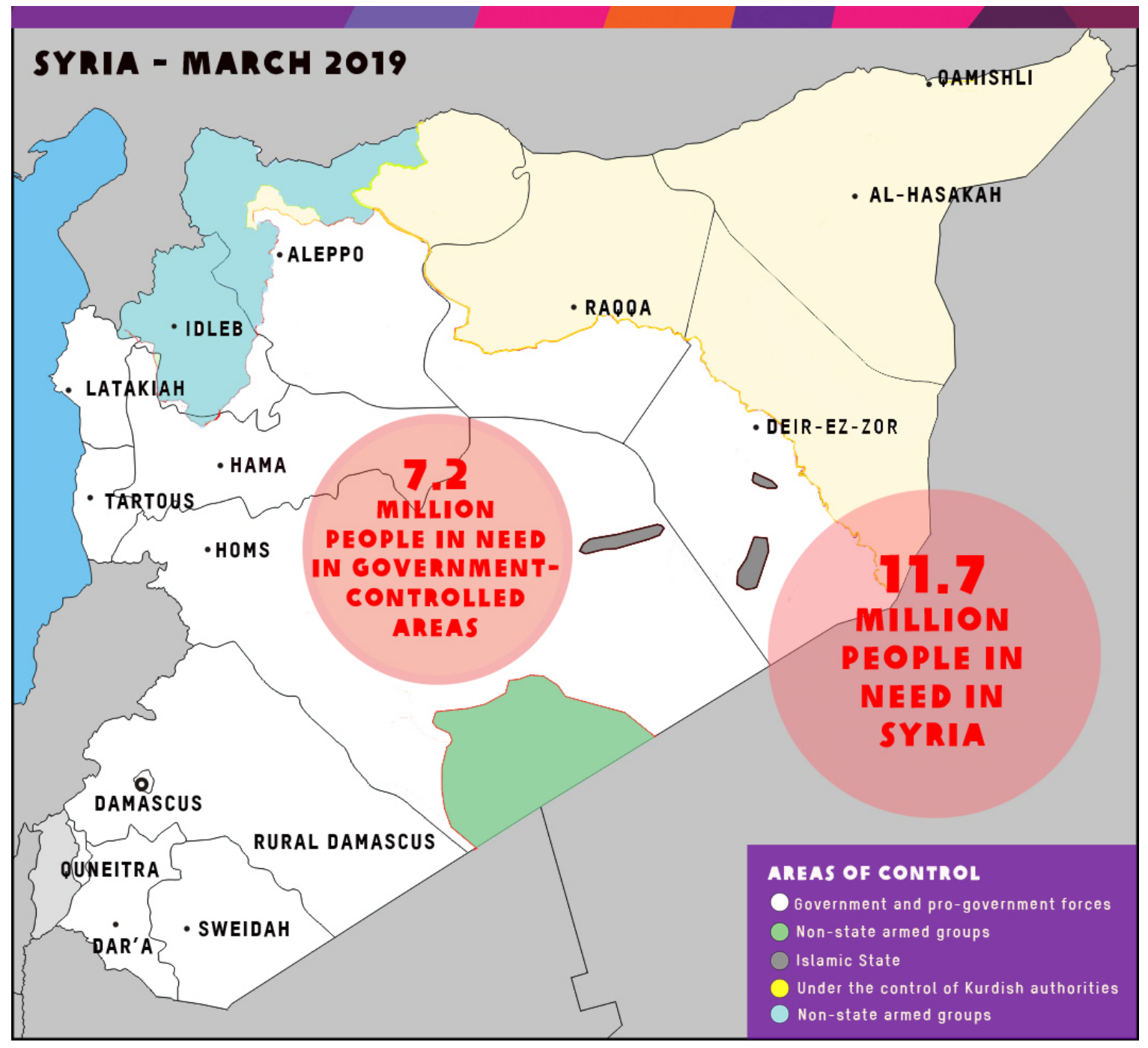

Although the risk of a resurgence in conflict remains, where possible people need support to increase their self-reliance and reduce their dependence on aid - they need support to begin the process of recovering. This includes programming to increase access to basic services including water and sanitation, education and healthcare, and to enable people to provide their own food by supporting their access to livelihoods and economic opportunities. 
The Global Cluster for Early Recovery defines early recovery as 'addressing recovery needs that arise during the humanitarian phase of an emergency, using humanitarian mechanisms that align with development principles. It enables people to use the benefits of humanitarian action to seize development opportunities, build resilience, and establish a sustainable process of recovery from crisis. ${ }^{, 4}$

Time and time again, these are the types of support Syrian civilians tell humanitarians they want: 'Water trucking needs to come with network repair. Food handouts can't end until there is food available in local markets or people can grow more food... people realize relying on handouts is not sustainable for them and they need to find a way to earn an income. ${ }^{5}$

While there is some support for such initiatives, it remains relatively limited. Due to the Government of Syria's restrictions on humanitarian access, combined with political considerations of donors in their interactions with government structures, humanitarian actors are not able to sustainably provide people with access to basic services and livelihoods.

This briefing paper examines the potential and the challenges for conflictsensitive early recovery programming in government-controlled Syria. ${ }^{6}$ Poor and marginalized people have a right to be heard and to voice their needs. ${ }^{7}$ Principled, sustainable access and financial support for such programming is vital to enable Syrians to live their lives with dignity and claim their right to a better life. The paper argues that a tendency to conflate early recovery programmes with reconstruction, and to avoid anything that politicians believe could be interpreted as contributing to reconstruction, is limiting humanitarian assistance and reducing options for dignified, sustainable and cost-effective support.

For many donors, 'anything is a slippery road to reconstruction'; ${ }^{8}$ that is, their lens appears to be state legitimacy and infrastructure - as they experienced it in Afghanistan, Iraq and Somalia ${ }^{9}$ - rather than the needs of conflict-affected Syrians.

There remain huge emergency needs in Syria, including in areas that are not under government control. These needs must be urgently met, and unrestricted and unhindered access provided to facilitate an effective humanitarian response - utilizing all access modalities.

However, for millions of others, the needs are changing, and this paper focuses on their needs. Danish Refugee Council (DRC) and Oxfam do not believe that early recovery support should be delivered at the expense of humanitarian support; nor do they believe that populations should be deprived of assistance to begin the process of recovery because emergency needs lie elsewhere. All three pillars of the 2019 Humanitarian Response Plan - life-saving assistance, protection, and access to basic services - therefore need to be fully funded. ${ }^{10}$ Delivering principled humanitarian action on early recovery in those locations where it is needed must be balanced with ensuring that all areas of Syria requiring life-saving assistance are able to receive it, as part of a Whole of Syria aid response. 
Supporting communities to begin to recover will be a complex process. The realities of the scale of destruction and levels of violence, ongoing protection concerns, limitations on access, risks of aid diversion, donors' political considerations and risk appetite, and corresponding practical difficulties linked to sanctions and bank de-risking all pose challenges to humanitarian organizations. There are no simple answers - but we collectively owe it to the people of Syria, who have borne the brunt of this crisis, to confront these challenges.

\section{Box 1: Our programmes in Syria}

$\mathrm{DRC}^{11}$ and $\mathrm{Oxfam}^{12}$ are two of the largest international NGOs operating with registration from Damascus. In 2018 we worked in nine of Syria's 14 governorates, including in Aleppo, Dar'a, Deir Ez-Zor, Hama, and Rural Damascus (including Eastern Ghouta).

Our collective work includes:

Provision of water, through repairing water sources and the water network, installing communal water and sanitation facilities, and supporting household-level repairs.

Sanitation: repairing sewage networks to prevent contamination of the water table.

Hygiene promotion: distributing hygiene materials including soap, washing powder, nappies and female hygiene products, and conducting awareness sessions in communities and schools.

Food security and livelihoods, including distribution of seeds and assets to farmers, cash for work programmes and supporting women and men to gain new skills through vocational training.

Access to education, by creating opportunities for children and youth to return to school or renew education through self-learning initiatives, rehabilitating learning spaces and schools, distributing teaching and student learning materials, and providing skills training for youth.

Emergency shelter, through rehabilitation of emergency shelters for displaced families, and repair of damaged homes for returnee and host communities.

Mine risk education: provision of teachers with a training of trainers (ToT) on risk education on unexploded ordnance (UXO) and explosive remnants of war.

Protection: child protection, skills development and psychosocial support activities. 


\section{THE SCOPE OF THE HUMANITARIAN RESPONSE FROM DAMASCUS}

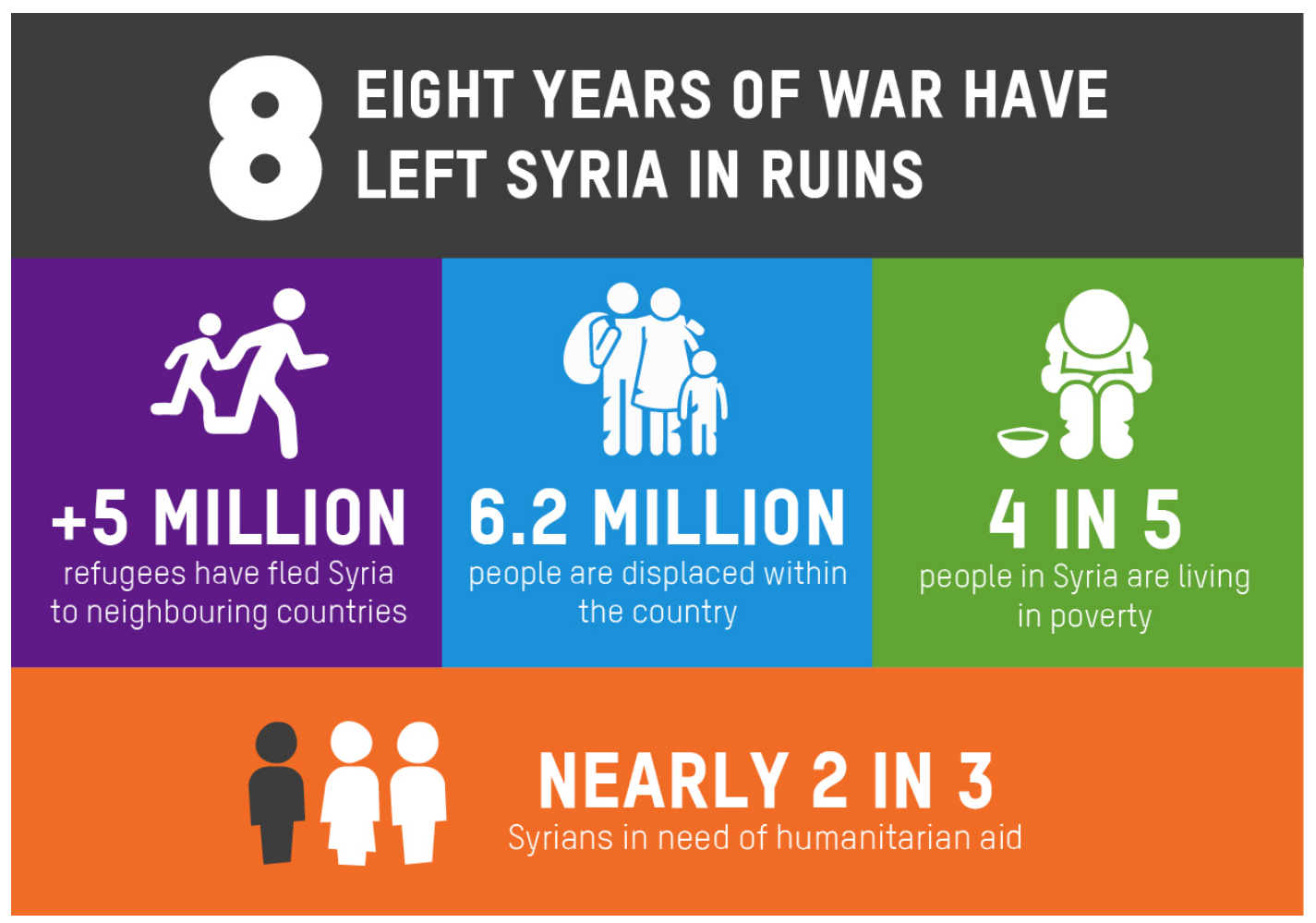

After eight years of crisis in Syria, millions of Syrians continue to find themselves in desperate need of humanitarian assistance, with 11.7 million people remaining in need and 5 million in acute need. Of the 11.7 million in need, 7.2 million live in areas under the control of the Syrian government. ${ }^{13}$

Throughout 2018, the humanitarian response in Syria provided life-saving, multisector humanitarian support through multiple modalities, including from agencies based in Damascus and by those providing cross-border aid. ${ }^{14}$ However, significant shifts in control mean many areas that were previously served by cross-border aid and aid delivered across conflict lines from Damascus ${ }^{15}$ are now only being served by Damascus-based humanitarian actors. ${ }^{16}$

As those changes of control took place - whether due to military force, by negotiation or a combination of the two - humanitarian actors were left to address a complex mix of needs in different locations across the country.

Timely and sustainable access to communities in government-controlled Syria has significantly limited effective programming at scale. The approvals process remains opaque and complex. Discussions with local government stakeholders and technical line ministries help to some extent. But these cannot substitute for the more sustained access that enables the regular community engagement needed to deliver gender-responsive programming that meets the needs of vulnerable populations, including people with disabilities. 
Yet where access has opened up, humanitarian actors consistently report a lack of funding to support people with a needs-based, principled, multi-sector response. This has particularly affected international NGOs (INGOs) operating from Damascus. Of the $\$ 2.2 \mathrm{bn}$ of aid provided in $2018,{ }^{17}$ only around $\$ 120 \mathrm{~m}$ was channelled through Damascus-based INGOs. ${ }^{18}$ Funding to governmentcontrolled areas is also provided by the UN under its regular programming.

Throughout 2018, Damascus INGOs often reported that programmes were not funded by donors because they were proposed for areas of the country controlled by the government. ${ }^{19}$ This has had obvious implications for organizations' abilities to respond based on need and vulnerability. 


\section{CURRENT EARLY \\ RECOVERY SUPPORT IN GOVERNMENT- CONTROLLED AREAS}

Oxfam and DRC's position is that aid can only help to achieve peaceful and safe societies when it is impartial, needs-based, poverty-focused, owned by and responsive to the people it is intended to assist, and independent of military and security objectives of the state and donors. ${ }^{20}$

There is still a great deal of need in Syria for life-saving humanitarian support, but in this protracted crisis thought must be given to early recovery and the eventual rebuilding of Syria - something which is likely to cost hundreds of billions of dollars. ${ }^{21}$ If funding is used in a way that could reinforce existing or long-term grievances, conflicts could resurface - something that happened after $60 \%$ of armed conflicts between 1946 and $2016 .{ }^{22}$ The UN and World Bank have called on aid actors to apply a 'nexus approach' (working together across humanitarian, development and peace-building operations) to make aid more sustainable and ensure that it deliberately attempts to prevent conflict recurring. ${ }^{23}$

As in many other conflict contexts, early recovery outcomes have been mainstreamed in the Syria Humanitarian Response Plan (HRP) since the beginning of the conflict. However, in October 2018, a joint donor paper to UN leadership indicated a possible reduction in support for early recovery programming - going directly against principles of good donorship, which support early recovery ${ }^{24}$ and state that humanitarian interventions should be guided first by conflict-affected people.

The 2019 HRP shows that the key support conflict-affected Syrians want is access to basic services including safe water, healthcare and education services, and economic opportunities, alongside safety and security. ${ }^{25}$

Prior to the conflict, Syria had public services that reached large proportions of the population, although as part of a centrally managed state with little social accountability. Water-supply coverage in 2010 was $98 \%$ and sanitation coverage was $97 \% .{ }^{26}$ This means that unlike many other conflict-affected countries, in Syria early recovery programming can reconnect people to basic services while increasing social accountability, if it is done well.

Since 2013, Oxfam's water, sanitation and hygiene (WASH) response to the crisis has worked in this way - making small repairs to water and sanitation pipelines, and rehabilitating water sources and pumping stations. With the number of hours of water supply often limited, household water tanks help families to store water from public systems. For Syrians, this is preferable to relying on private sector water trucking, which comes at hugely inflated costs, adds risks of secondary contamination and worsens protection outcomes.
'There's no home, no electricity, no water, no schools. How will my kids go back to school?' - Jawaher, Syrian refugee in Jordan 

cost-effective. $^{27}$

\section{Box 2: Providing water at a household level}

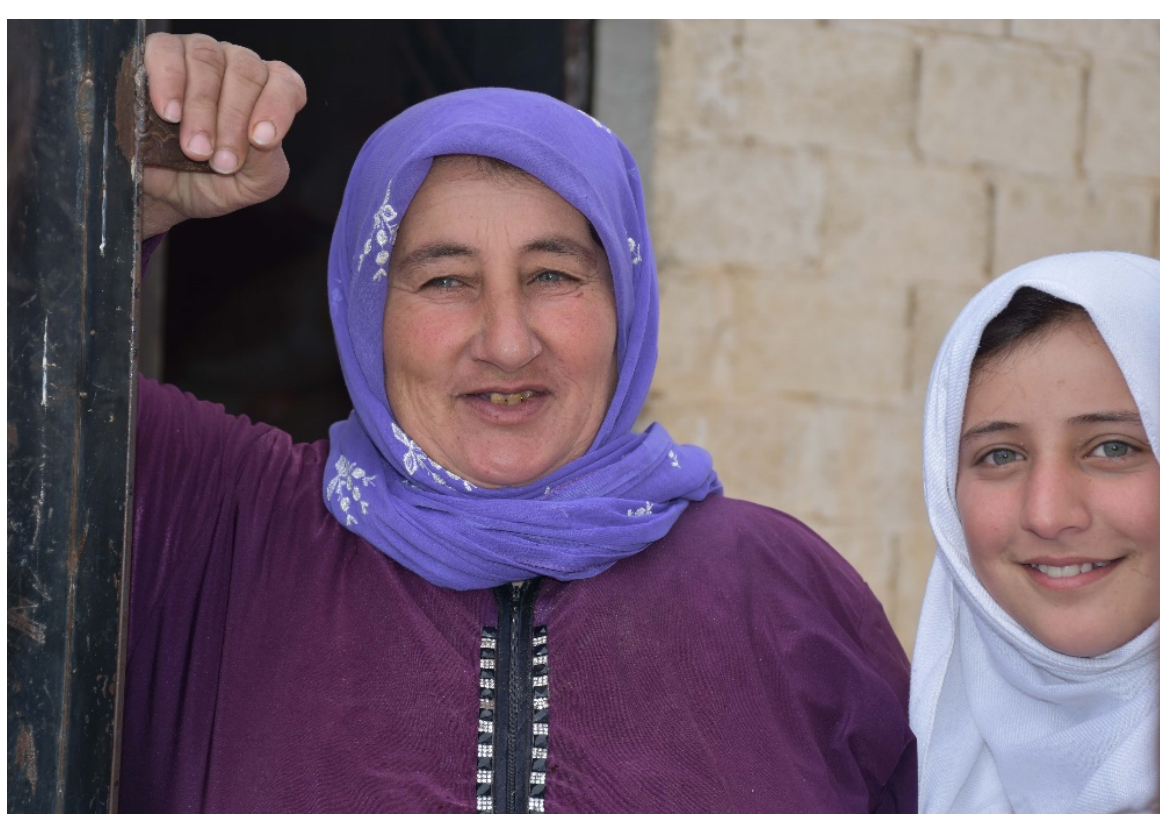

Ahlam, 55, stands with her granddaughter next to her home in Jebreen, north of rural Hama. With her family, she used to suffer from lack of clean drinking water, which was supplied once a week. Photo: Dania Kareh/Oxfam.

55-year-old Ahlam lives with her family in Jebreen, north of Rural Hama. The local network only delivers water once a week, which created a daily struggle for Ahlam, her family and hundreds of others like them:

'We tried to store as much water as we could, but we still had to spend 1,500 SYP (\$2.91) every month for water that was delivered by truck. This is a lot of money for us now.'

Oxfam equipped and restored two wells and linked them to the local water network, providing over 40,000 people with sustainable access to clean water.

'Now the water network is more reliable, we can spend that money on other things,' says Ahlam.

Wafa'a, 58 , who has returned to Douma, told Oxfam, 'I currently pay $8 \%$ of my income on buying trucked water from a private company. At the moment, it is the only way I can be sure of getting safe, clean water.' 
In Eastern Ghouta, it costs Oxfam approximately $\$ 4.6028$ per 1000 litres to truck water, compared to approximately $\$ 27,800$ to repair a well that provides 52,000 litres of water per day. Over five years, it would cost just over $\$ 44,500$ to keep providing this amount of water. Trucking this quantity of water for one year alone would cost over $\$ 87,000$. $^{29}$

\section{How much does 1000 LITRES
of water per day cost}

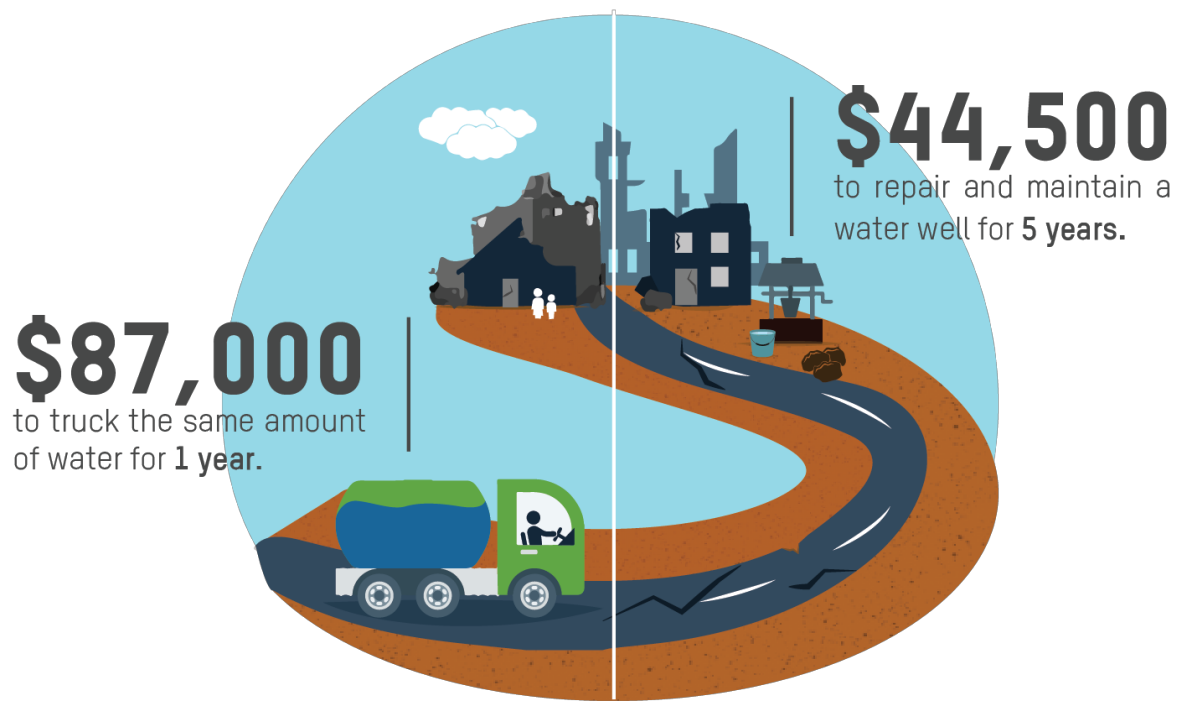

Supporting small repairs is not only MORE SUSTAINABLE, IT IS SIGNIFICANTLY MORE COST-EFFECTIVE

While Oxfam has identified water network light repair as a more sustainable response than water trucking, the approach also has protection benefits as communal distribution points or water tanks come with a higher risk of genderbased violence (GBV) for women and girls collecting water. Reducing the time people have to spend on water collection also increases their opportunities to earn an income - this is especially true for female headed-households.

Oxfam has also been increasing multi-purpose cash support to vulnerable communities in line with Grand Bargain commitments. ${ }^{30}$ Since July 2018, Oxfam has provided unconditional cash transfers to households in areas including Rural Damascus, Deir Ez-Zor and northern Aleppo; as well as cash-for-work support in south Aleppo and eastern Deir Ez-Zor, including some rehabilitation of irrigation canals for small-scale farmers.

Within the education sector, by working in cooperation with local authorities and the Ministry of Education, DRC has rehabilitated and repaired over 135 that were damaged by conflict. Transforming these building into 'Welcoming Schools' in time for the next academic year is one step towards helping reconnect Syria's 2.1 million out-of-school children ${ }^{31}$ with learning. DRC fully equips functional classrooms and provides teacher training, materials and technical support to enable a more inclusive and quality learning environment.

'It's a great feeling to have the ability to meet your own needs and not rely on handouts.'

- Suhad, a widow and mother of five living in Eastern Ghouta. Suhad received unconditional multi-purpose cash support from Oxfam. 


\section{Box 3: Community-driven market recovery}

DRC uses micro-grants to support local market recovery in a communitydriven manner. In 2018, 433 people who had lost their livelihood in the conflict were supported to re-start businesses. The grants were accompanied by business development training to build the capacity of micro-business owners to adapt to current market needs, including by supporting groups of business owners to jointly establish workshops in urban communities that had been heavily affected by conflict.

For example, in Homs old city, DRC supported displaced people to re-start carpentry and upholstery businesses. They jointly established a workshop in the city, employing local residents and supporting returnees to purchase essential household items at lower prices. This reduced their reliance on assistance and increased access to income-generating opportunities.

Other types of early recovery support from organizations operating from Damascus include grants for small businesses; vocational training; kitchengarden kits; basic shelter rehabilitation; support to bakeries; and light repairs for classrooms and health centres to improve people's access to existing services. 


\section{WHAT NEXT FOR EARLY RECOVERY AND RESILIENCE INSIDE SYRIA?}

Conflict-sensitive early recovery inherently raises several complex issues and challenges, including when programming in government-controlled areas. All those involved in delivering the humanitarian response need to begin thinking and interacting differently to ensure that those who are in need receive the support they identify as most helpful to them. While early recovery assistance and reconstruction exist on a continuum, none of these areas of focus or subsequent recommendations fall into reconstruction - they are about trying to deliver the right type of assistance in the right way.

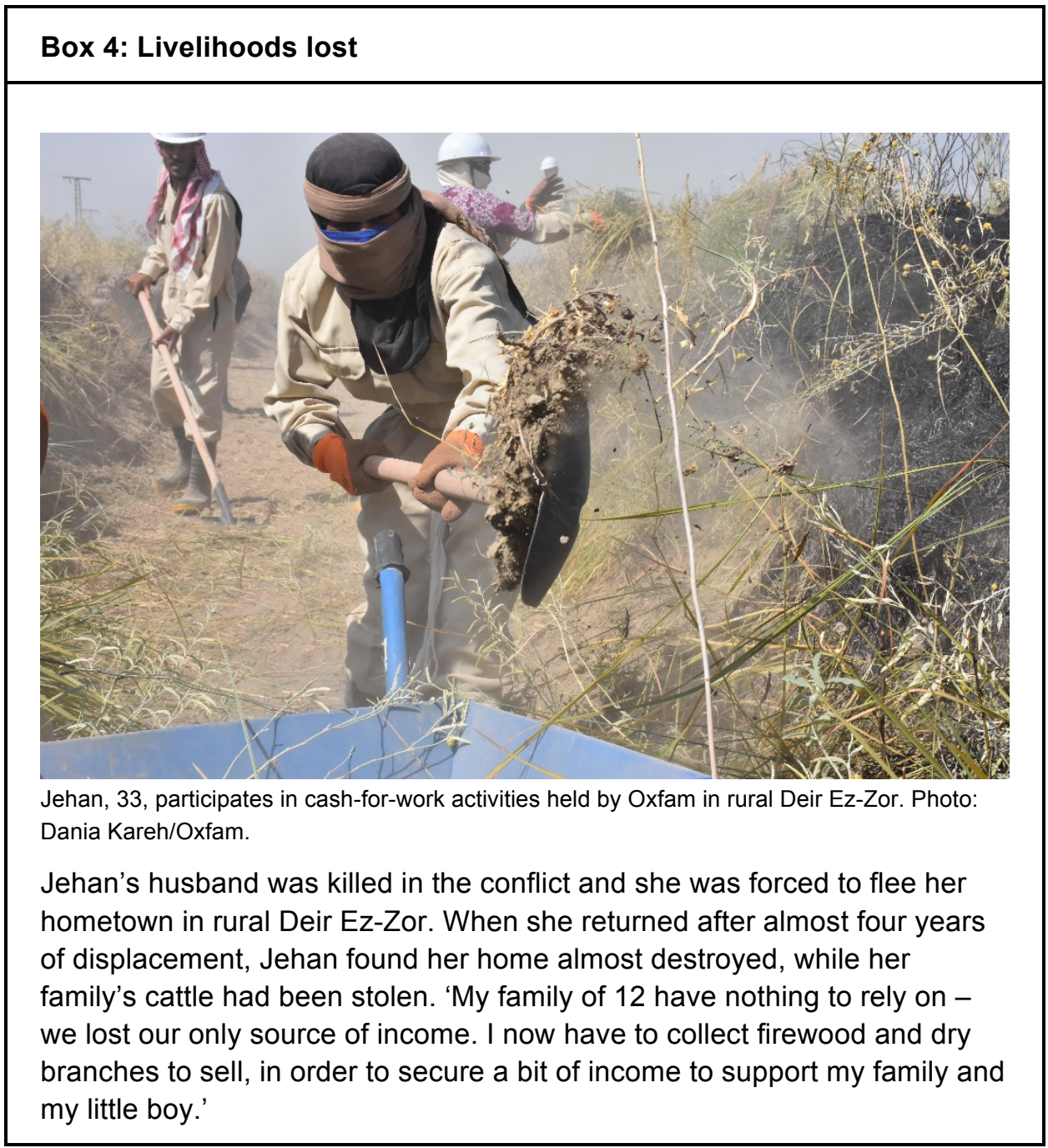

Decision making will need to be centred on the preferences of ordinary Syrians, including their aspirations for the future. ${ }^{32}$ Yet despite their stated preference for the restoration of basic services, in practice this has become harder to fund and implement in government-controlled Syria in recent months. ${ }^{33}$ One UN representative in Damascus said, 'Some donors are trying to get over this by 
having maximum monetary values, for example $\$ 25,000$ for a school. But this ignores the true needs and requirements of a community. ${ }^{34}$

According to one INGO representative, 'Some donors have cut livelihood programmes completely. It's not sustainable aid. [It's] throwing things onto the fire, but the fire isn't going to go out because you aren't tackling the issues. ${ }^{35}$

Another said: 'We talked to 15 communities in Deir Ez-Zor in August 2018 and they asked for two things. First, they wanted us to rehabilitate their irrigation systems because they want to restart farming; and second, bakeries, because there isn't enough bread. ${ }^{36}$ However, when the organization sent a proposal to support electricity supplies for bakeries so they could provide bread to local communities on an ongoing basis, the donor would only support bread distribution - meaning that communities risk being given aid which does not align with their expressly stated requests, and that the support is not sustainable - people's access to bread will stop when the funding stops. ${ }^{37}$

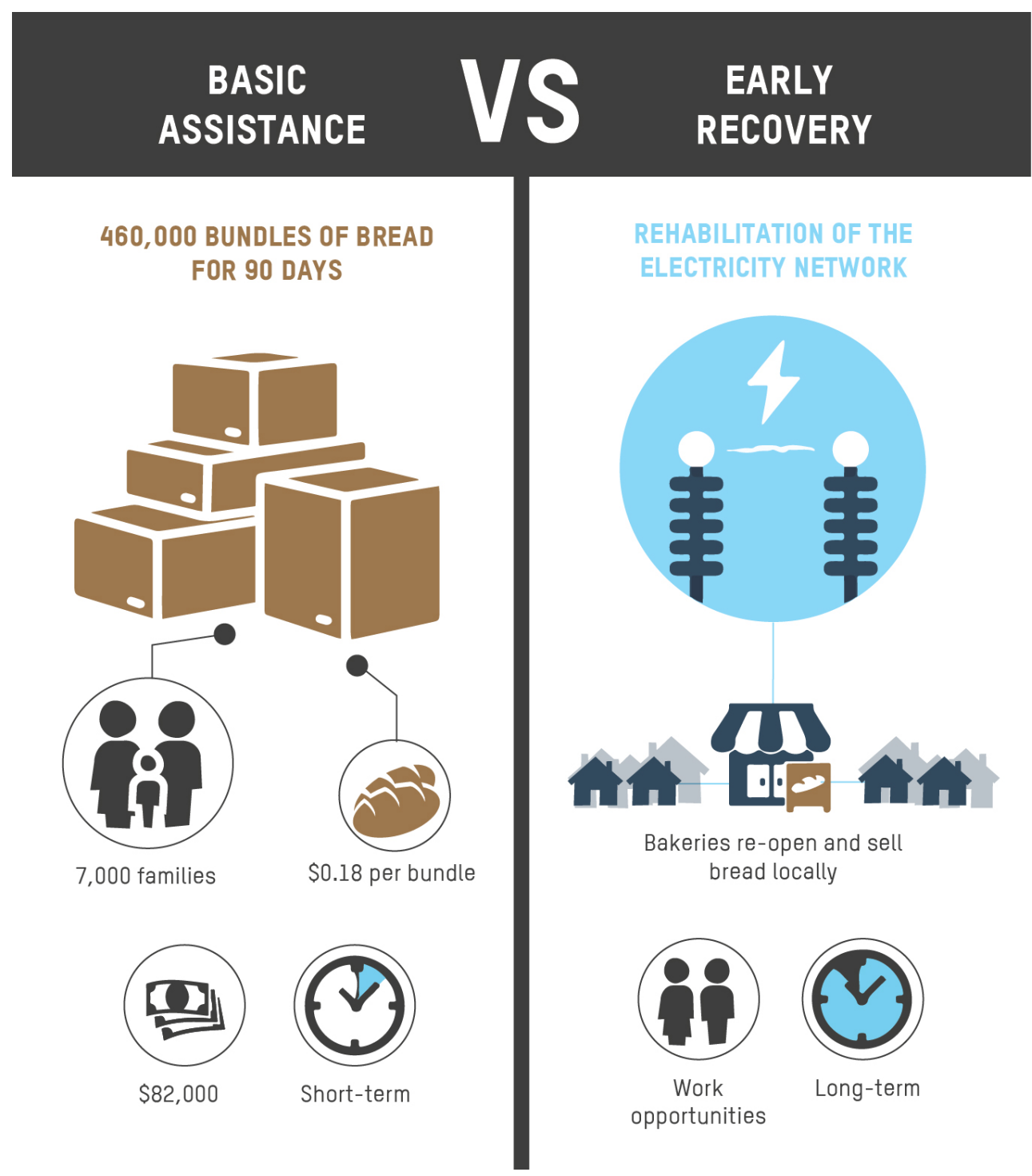

Women have highlighted their wishes for vocational training and small business grants that support women's economic empowerment. Immediate and long-term needs should be considered to ensure that such training can facilitate longerterm resilience. ${ }^{38}$ 
However, many of the people that INGO staff speak to in Syria find it difficult to think about the future, given how damaging the last eight years have been.

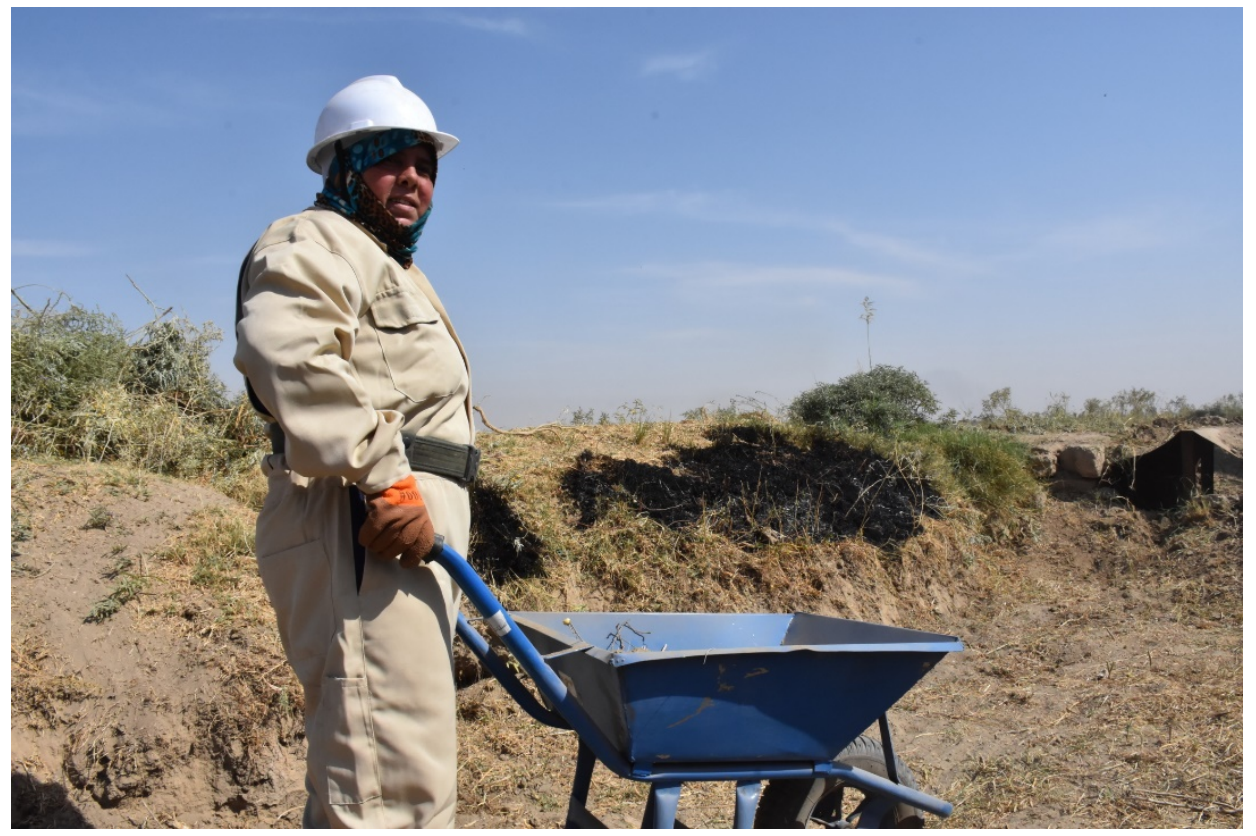

Wafa'a fled the conflict in 2014 and recently returned to her home in rural Deir Ez-Zor. 'We returned seven months ago and now we have nothing to rely on to start to work again in agriculture. With water being available again, the situation will improve. A new life will start and the conditions will change.' Photo: Dania Kareh/Oxfam.

\section{Box 5: Sanitation as well as water}

It is increasingly difficult to find donors who are willing to fund sanitation and solid waste management because of a perception that these activities are 'development', despite their inclusion in the HRP. ${ }^{39}$ Contamination of the water supply by sewage is of particular concern in newly accessible areas that sustained heavy damage during the fighting.

A lack of solid waste management provision and damage to communal waste bins during the conflict has led to the dumping of waste, including food waste, increasing the prevalence of flies and disease. Leishmaniasis, a parasitic disease carried by flies, has become common in communities across Syria, with a recent increase in cases in Deir Ez-Zor. Leishmaniasis can cause skin lesions, which can lead to permanent disability. If it infects the organs it can be fatal.

Investment in solid waste management, including the provision of communal waste bins, is crucial to maintaining the health of local populations. 


\section{ENSURING THE CENTRALITY OF PROTECTION WITHIN EARLY RECOVERY PROGRAMMING}

Continuing and expanding early recovery programming will require close attention to protection issues inside Syria, in line with the IASC Principles commitment to ensuring the centrality of protection in humanitarian action, ${ }^{40}$ and ensuring the reduction of negative coping strategies by populations in need. ${ }^{41}$

This will be particularly important with regards to people's access to civil and legal documentation including marriage certificates, family booklets, birth and death certificates and housing, land and property (HLP) documents.

'Unless these [legal issues] are sorted, it's going to be difficult to do recovery, let alone reconstruction. It impacts your rights to stay or return. We can't build systems around people who aren't secure.' - UN agency representative, Damascus. $^{42}$

Documentation is essential for everyday life - for people to be able to eventually return home, enrol in school and sit exams, and move freely within the country. Despite equality under the Syrian constitution and laws, women have historically struggled to claim their HLP rights, as social norms mean they are often not named on land or property deeds, making it difficult for them to demonstrate ownership. The fact that they do not have the right to pass on their citizenship to their children also poses serious challenges, including the risk of statelessness and resultant lack of access to HLP rights for their children. Lack of access to legal services, traditional social norms (including religious norms) as well as forms of violence against women also impact women's abilities to claim their rights. This is especially problematic for widows or women whose male relatives are at risk of conscription. ${ }^{43}$ Almost one in three households in the country are now headed by women, ${ }^{44}$ and specific legal assistance will have to be put in place to support them. Attention will also need to be paid to former and current rural populations - both women and men - whose land and property may never have had any formal documentation. Demonstrating historical occupation may prove additionally challenging where populations have been displaced.

Agencies need to be prepared to support access to documentation, and more need to be allowed to do so. ${ }^{45} \mathrm{~A}$ considered, coherent approach is required to ensure that the absence of formal documentation does not result in complete dispossession of property, permanent displacement and a lack of access to aid.

Programmes also need to be aware that some people can move freely while others cannot, often due to fear of conscription or lack of documentation.

Following the collapse of some buildings in eastern Aleppo, plans to remove people from other properties have come without clear plans for their long-term support, ${ }^{46}$ including re-housing or compensation. Urban planning laws in Syria permit the central government to compulsorily purchase properties to allow for redevelopment, subject to rules ${ }^{47}$ set out by various pieces of legislation. While such legal mechanisms will be necessary, ensuring that people are able to equitably receive a just price for their land, access legal support, retain the right 
to live in their community, and that those displaced can equally access these rights, is crucial. Early recovery programming will need to consider these issues to ensure it provides sustainable access to services for those in greatest need.

This will require substantial investment in context and conflict analysis, including an understanding of population displacements in and from Syria during the crisis, and upholding the principle that those displaced have the right to return safely, voluntarily and in dignity. This will also help agencies to make sure that their targeting is accurate and appropriate - i.e. that populations most in need are receiving assistance. Currently, there is minimal visibility on internally displaced person (IDP) returns. ${ }^{48}$

\section{ADDRESSING THE EFFECTS OF BANK DE-RISKING ON CASH AND LIVELIHOOD PROGRAMMING}

Sanctions frameworks - and their chilling effects on banks' risk appetite - pose serious challenges for humanitarian programming of all types inside Syria. International financial sanctions not only limit the number of banks humanitarian funds can be transferred to, but also their onward transmission in-country. Sanctions also affect what sort of programmes can be run, and what items can be exported to Syria or purchased in Syria. Licences to dis-apply the rules exist but can be complex to obtain. International transfers depend on 'correspondent' banks - intermediary banks between the NGO's bank and a bank in Syria. It remains challenging to find new correspondent banks to ensure a reliable means to transfer money into Syria. International modalities for the transfer of funds can close with very short notice, leaving organizations scrambling to find different ways to ensure that funds reach the country to minimize disruption to programming.

Banks' risk appetite can also pose challenges for cash programming, despite clear donor commitments to cash under the Grand Bargain. In areas of the country recently retaken by the government, lack of electricity, destroyed or looted bank infrastructure and access constraints mean that physical cash can sometimes be the only modality possible. This raises concerns for many banks regarding the modality of beneficiary selection and means of delivery, the identity of any third parties involved in programme delivery and post-distribution monitoring. Their concern is the potential for aid diversion, which may mean that programmes fall foul of sanctions regimes - even with beneficiary registration and due diligence on the part of implementing NGOs.

Bank de-risking has caused INGOs to delay paying suppliers, in turn placing those suppliers and organizations' staff at risk within their local community, while INGO staff have been threatened by unpaid suppliers. It also restricts money transfer within Syria, on occasion resulting in large quantities of cash having to be transported long distances. 
In 2019, Oxfam plans to support 2,000 thousand farmers with agricultural inputs, including wheat and barley seeds, via three donor programmes. Wheat seed is only available in the country via the General Organization for Seed Multiplication (GOSM), a state institution, but one not subject to sanctions due to its importance for making bread - a staple of the Syrian diet.

Oxfam intended to purchase $100,000 \mathrm{~kg}$ of wheat seed, either directly through the GOSM or via a third-party vendor. However, because the GOSM deposits funds in a sanctioned bank, one donor was unable to authorize this purchase - nor was it willing to authorize cash support for farmers to purchase their own seeds because they would have to be procured through a state institution. As a result, Oxfam will have to consider providing different types of seed - reducing the programme's direct relevance to people's needs and preferences, and potentially undermining its long-term impact.

DRC operates six community centres providing over 18,000 people in Syria with protection and education services every year. Heating the centres during the cold Syrian winter is an annual challenge, because the only regular supplier of fuel inside Syria, the General Fuel Distribution Company (SADCOP), is affected by sanctions. This means DRC must seek out irregular, alternative fuel sources, which negatively impacts cost-efficiency and value for money.

The challenge to procure fuel has been particularly great this year, as the exceptionally cold winter coincided with severe fuel shortages across Syria. With sanctions constraining the import of fuel into Syria, DRC is exhausting its existing fuel stocks and to date has been unable to locate a new supplier for fuel, threatening the community centres with temporary closure if more fuel cannot be obtained.

While sanctions remain in place, donors must regularly review their impact with humanitarian partners to strengthen humanitarian exemptions, and work with their treasury departments and the private sector to minimize the risk of disruption to aid, and risks to the protection of humanitarian workers.

\section{ENHANCING THE ROLE OF LOCAL COMMUNITIES}

While levels of armed conflict may be decreasing in areas controlled by the government, this provides space for pre-existing social tensions to begin to reemerge and for potential new tensions to arise between host communities and IDP or refugee returnees.

Civic space inside Syria is heavily restricted, but it must be ensured that civilians in need can direct the type of assistance they receive, provide independent feedback on the quality of assistance and inform changes in programming to ensure that it better meets their needs. This should involve facilitating more consistent participation of women-led organizations and women's rights organizations across all interventions. 
All programmes should seek to bring communities together, be rooted in a 'Do No Harm' approach and ensure the protection of civilians. ${ }^{49}$

To ensure effective participation, Syrians need to be able to hold local decision makers to account in increasing access to services, and donors and international agencies to account for their humanitarian programmes. Separate spaces may be needed for women to engage, recognizing that social norms may otherwise prevent them from interacting with service providers and humanitarian actors, ${ }^{50}$ and women must also be represented in decision making positions, in line with good humanitarian practice. This is not reconstruction. The humanitarian response should ensure that local stakeholders, including the public sector, are involved in the overall planning of the response and that mechanisms are utilized to increase accountability both at a local level and with international humanitarian actors operating in Syria.

This work should focus on building relations in and between communities and local authorities, addressing localized tensions or concerns, and involving local Syrian organizations. It should emphasize building people's capacity to facilitate responses to local issues, including supporting local water and neighbourhood committees to be able to identify concerns and to raise them with local authorities. In DRC's experience, such analysis included having a strong knowledge of local dynamics and social tensions. This shapes decisions around where we work, how we work and with whom we cooperate.

\section{IMPROVING ACCESS FOR HUMANITARIAN ACTORS}

Ongoing challenges for obtaining access include a heavily bureaucratic system with multiple stakeholders; restrictions on independent needs assessments by humanitarian agencies; delays to approvals for programmes, activities, travel and work locations; visa restrictions; and limits on working with Syrian organizations.

To be able to deliver effective early recovery programming that makes a lasting impact, humanitarian actors need to have enhanced and sustainable access to communities across Syria. This includes ending restrictions on freedom of movement for humanitarian actors and allowing them to open sub-offices in areas where they are responding. This will support sustained engagement with local stakeholders and communities to ensure their support and that organizations can engage regularly with the people they serve - especially in parts of Syria where social, cultural and religious norms limit women's roles in the labour market.

Comprehensive information and data will be needed including market, valuechain and conflict sensitivity and local analyses. 


\section{Box 7: The complications of access}

'It took us one month to get agreement to move supplies between warehouses, and then we couldn't use the original driver and the process had to go right back to the beginning. ${ }^{51}$ - INGO representative, Damascus

An effective and transparent, programme- and area-based approval system is required, rather than the current system that relies on formal approvals for each intervention and movement of goods.

An approval mechanism of this kind - where dialogue with stakeholders is followed by a broader approval for a wider area that includes the ability for community engagement - will enable programming to be most effective and give Syrian people the opportunity to become self-reliant.

Organizations will need an expert skillset to deliver best practice programming from other similar contexts; this can sometimes require international staff with specific strong technical knowledge. They also need sustainable access to communities. As a UN representative put it: 'If you want to look at systems in Aleppo, you need to be based there for three or four weeks to get a real sense of how things work there. ${ }^{52}$ It is encouraging that more INGOs now have permission to establish offices in Aleppo, and this increase in access needs to be built upon.

As Syrians make up the clear majority of aid workers, it is vital that they are protected from violence and discrimination.

\section{ENSURING COHERENT AND PRINCIPLED ENGAGEMENT BY HUMANITARIAN AGENCIES}

International agencies operating from Damascus can and are finding ways to operate in a principled manner inside Syria, despite the obstacles. However, negotiating access is time-consuming, and the challenges regularly lead to delays in delivering assistance and severely curtail the scale of responses. If humanitarian actors and donors are to be able to effectively respond to needs (in whatever form these needs take) in government-controlled areas, negotiating an improved operational environment must be a priority. To ensure coherent and principled engagement, INGOs must:

\section{- Be guided by humanitarian principles at all times ${ }^{53}$}

No interventions should take place that do not align with the principles of impartiality, independence and operational neutrality. This includes ensuring that independent needs assessments are conducted and vulnerability criteria applied to the selection of people for whom the assistance is intended, and that there are no actors involved who have a non-humanitarian motive. There should be a clear policy of zero tolerance of interference with procurement and recruitment processes. 
Agencies must also be clear that they will only take funding from donors for programmatic responses that are solely based on need and vulnerability, without political conditions, and that they will withdraw from any intervention if there are unacceptably high risks of aid diversion; SGBV; conscription at aid distribution points for men and boys; if there is a presence of military forces at the project or intervention site; or if safeguarding and protection concerns cannot be effectively mitigated.

\section{- Underpin all work with a conflict-sensitive approach, centred on protection and a Do No Harm framework}

All work inside Syria must be grounded in an understanding of conflict dynamics at a national and local level, and INGOs should take practical steps to, at the least, avoid exacerbating conflict or tension (including within and between communities); reinforcing negative state practice; causing harm to individuals or communities; or undermining local markets. This includes undertaking a clear analysis of how short-term actions can sustain or undermine long-term solutions, reinforce conflict dynamics and lead to negative consequences in people's lives. ${ }^{54}$

Given the lack of available reliable data in Syria, including from before the crisis, organizations will need to share more of the information they do have which can help to provide a more nuanced understanding for the response. This includes, for example, information about the number of checkpoints that economic and humanitarian activities face and a shared analysis of government policies and announcements, including development plans,. Organizations must understand the interaction between local and national governance actors, and relative civic space, rights protections and restrictions.

Humanitarian actors must also assess the dynamics of IDP and refugee return and ensure that programmes are designed and implemented by needs, not status, and uphold durable solutions principles, while appreciating the potential different needs of returnees.

Early recovery programming requires working closely with communities and local authorities, and such opportunities should be capitalized on under the Do No Harm framework. This is not reconstruction, this is good programming.

\section{- Be gender-responsive}

A principled humanitarian response must fully incorporate gender and women's perspectives at all stages of programme design and implementation as well as monitoring and evaluation processes. Simply restoring the status quo in a context in which existing social structures marginalize women leaves women just as vulnerable as they were before.

Special attention must be paid to creating spaces in which women can effectively engage, bearing in mind cultural, legal and social barriers to their effective and meaningful participation, including assessing the impact of genderblind development policies; women's lack of access to decision makers; and some legislation that favours male next-of-kin over women in terms of property tenure. ${ }^{55}$

Households whose main income provider is female face specific vulnerabilities, such as having less access to resources, including aid. However, interventions 
that simply target women based on their status as head of household can actively put women at risk, including of domestic violence and SGBV. ${ }^{56}$

\section{- Develop common standards for the humanitarian response}

The Whole of Syria aid infrastructure has enabled the international aid community to reach populations in need in line with humanitarian principles. However, this has come with significant communications challenges and limited information sharing.

This situation needs to be urgently addressed to ensure that all humanitarian actors can coordinate effectively. Within government-controlled Syria, all humanitarian actors must provide clear and up-to-date information about who is operating, or has capacity to operate, in each community.

Ensuring that organizations adhere to common minimum standards should also create space for collective advocacy with authorities, especially on access. This should explicitly address mutual accountability between donors and their partners operating in government-controlled areas, particularly given that some of the challenges facing Damascus-based organizations stem from the role of politics within aid decision making (by donors and the Government of Syria). ${ }^{57}$ 


\section{DONOR RELUCTANCE TO FUND EARLY RECOVERY}

Early recovery - like all humanitarian assistance - is needs-based, genderresponsive, targets vulnerable communities, is based on humanitarian principles, has a clear focus on protection and is implemented in a conflictsensitive manner. By contrast, reconstruction focuses on the state and its capacity, not on people. It is not impartial, needs-based or people-focused. ${ }^{58}$ These important differences between early recovery and reconstruction must be more clearly recognized.

Alongside sustained access, one of the most critical challenges to increasing early recovery work where it is appropriate is donor reluctance. Many donors view being politically willing to fund early recovery as legitimizing the Government of Syria, and many will not discuss support for reconstructing Syria until some form of political transition is under way. ${ }^{59}$

This is not to say that there is a unified donor position, or that no early recovery or resilience funding is being provided. Oxfam, DRC and other humanitarian actors have been able to carry out early recovery work precisely because of donor support. However, the donor community has tended to provide humanitarian actors with an inconsistent approach to delivering recoveryfocused projects, which often goes against donors' global approach to resilience. For example, the EU's Integrated Approach to External Conflict and Crises ${ }^{60}$ commits the EU to considering the long term while utilizing short-term engagements and actions, yet this is not the approach in Syria. Many INGOs are raising concerns that early recovery funding is becoming increasingly difficult to find.

International experience shows that reconstruction often increases inequality and promotes a vision of 'negative peace' (i.e. where conflict has stopped, but underlying issues remain ${ }^{61}$ ) more than it seeks to prioritize community-based and transformative approaches that address root causes, respond to the legitimate needs of all, and promote inclusive and just governance. ${ }^{62}$ The reconstruction 'debate' about Syria should remain focused on these often sidelined outcomes, and any future support for reconstruction must be preconditioned on ensuring a more peaceful, fair, accountable and just future for the country. Getting early recovery right can build a better base for more peoplefocused, conflict-sensitive reconstruction in the future.

The concerns around reconstruction are valid - but they do not mean there should be no early recovery or support for community-level resilience work, including for populations living in government-controlled areas of the country.

Too often early recovery and reconstruction objectives are being conflated. For example, Oxfam has found that while donors are willing to fund discrete rehabilitations to the water network, it is more challenging to secure funding for the repair of sewage networks - even where their failure is responsible for contaminating the water supply. Similarly, organizations responding in the health and education sectors find that staff training is prohibited, even though there is a 
clear need for qualified teachers and nurses to enable a functioning system. ${ }^{63}$ Meanwhile, despite a focus on immediate protection benefits, funding for street lighting appears to be impossible to attract, ${ }^{64}$ even though its provision can increase freedom of movement and safety.

This situation is in part due to the legitimate concerns about principled access, appropriate targeting and risks of diversion or contributing to the war economy. These are real risks across Syria, and responding to them requires substantial investment, time and energy from agencies operating in-country. But there are also concerns that many of the technical discussions that organizations and donors need to have about moving from emergency response to more effectively supporting people in the longer term are simply not possible because political strategies are trumping humanitarian imperatives and the principles of good humanitarian donorship. A representative from an INGO in Amman said: 'Donors are talking a hard line, but everyone is getting confused. We need to think about outcomes for Syrians. ${ }^{65}$ If strategy begins with a political commitment rather than a focus on people, then, as one donor said, 'we hit a red line'. 66 


\section{CONCLUSION}

'Seeing the scale of the destruction, you'd think it would be impossible for us to have the life we once did in Aleppo. But here she is, the city, very slowly recovering. I do still have hope that this day will come soon.'- Khaldieh, grandmother raising her two orphaned granddaughters, Aleppo

Parties to the conflict in Syria have destroyed not just buildings, public services and people's homes, but also the social fabric of the country and the local assets that helped people to sustain their lives. Children have missed out on school, businesses have closed, and the public and private sectors have lost thousands of talented individuals who have fled the war.

The crisis in Syria is still not over, with increasing tension in both the north-west and the north-east, areas that remain outside of the control of the government, and the continued involvement of - and proxy wars between - foreign military forces.

Nonetheless, several communities across government-controlled Syria are no longer facing active conflict and have different, although no less important, needs for the humanitarian response to serve. Despite a challenging operational environment, humanitarian donors and actors should work to ensure that these needs are met effectively as part of a gender-responsive, people-centred, response.

The Syrian people should not be paying the price of geopolitical decision making. Humanitarian aid should be depoliticized, based on need and delivered in line with the Good Humanitarian Donorship principles - which highlight the need to consider recovery and access to livelihoods in humanitarian programming. ${ }^{67}$

In what is a protection crisis, increasing access to basic services, helping children back to school and providing more women with livelihoods opportunities can deliver immediate protection benefits, including reducing risks of GBV and the use of negative coping strategies. It also gives people greater agency in their own lives and affords them dignity - something humanitarians aim to put at the heart of all responses.

While these are significant challenges, a failure to support Syrian people to become self-reliant will create a population dependent on aid and enhance the status of those who have gained from the war economy. At worst, it could result in exacerbating the root causes of the conflict. The Syrian people deserve a humanitarian response that meets their needs, upholding their dignity. If, after eight years of war, the humanitarian response is not yet able to support Syrians to support themselves, then when will the time come? 


\section{RECOMMENDATIONS}

\section{TO DONORS}

- Commit to funding all activities identified as part of the HRP, including the third pillar on early recovery and livelihoods support on the basis of need, regardless of who is in control.

- Increase longer-term, flexible humanitarian funding (at least 24 months), supporting organizations working from Damascus to implement communitydesigned programming and negotiate the approvals process, recognizing that bureaucratic hurdles can prevent the immediate start of projects.

- Continue to support programmes that repair existing infrastructure to increase civilian access to basic services, social service delivery and sector management capacity, with a focus on services that provide an immediate protection benefit. Programmes should be targeted based on needs and vulnerability.

- Support individuals to resume or strengthen food production activities and capabilities to increase household food availability and enable income generation.

- Support programmes for conflict-affected Syrians to access livelihoods, including vocational training programmes and grants to small- and mediumsized businesses, and the rehabilitation of local markets and value chains for new business opportunities. Programmes should be gender-responsive and support women entering new sections of the economy, be conducted in line with a market and value-chain analysis, and target people according to need and vulnerability.

- Require and provide support for humanitarian actors to produce coherent conflict-sensitivity strategies to underpin collective early recovery and resilience strategies for areas under government control, in addition to individual projects.

- Support Damascus-based organizations to develop operational procedures and common standards for operations out of the hub, including agreed modalities for more effective risk sharing between humanitarian organizations and donors.

- Ensure that donors follow standards of principled engagement inside Syria.

- Ensure all programmes adhere to Core Humanitarian Standards.

\section{TO THE GOVERNMENT OF SYRIA}

- Reduce bureaucracy around approvals, including for needs assessments and programme monitoring, and to increase transparency and reduce delays in approval processes.

- Ensure free movement for all humanitarian staff to work regularly and freely in areas of need. 
- Ensure any and all military acts do not cause harm to civilians or civilian infrastructure, and adhere to International Humanitarian Law.

- Allow more organizations to work from Damascus, enabling the humanitarian response to reach more people in need.

- Ensure that Syrians, including Syrian women, are able to access civil and legal documentation that protects their housing, land and property rights, and ensure that support can be provided to populations without documentation, enabling humanitarian actors to develop programmes around stable populations.

- Facilitate visas for permanent and temporary expert international staff who can develop and support effective early recovery programming, and facilitate their greater movement across Syria.

- Enable humanitarian actors to effectively deliver programmes in all three pillars of the HRP, ensuring that programmes can be gender-responsive, follow IASC Protection Principles and can be delivered in line with Core Humanitarian Standards.

\section{TO ALL PARTIES TO THE CONFLICT}

- Ensure that any and all military acts do not deliberately cause harm to civilians or civilian infrastructure, and adhere to International Humanitarian Law.

- Facilitate unimpeded humanitarian access to populations in need.

\section{TO THE UNITED NATIONS}

- Take a leadership role in advocating for early recovery programmes that increase access to basic services and build resilience, while ensuring emergency life-saving needs are also met.

- Increase dialogue with donors and INGOs to share conflict and risk analyses, and to ensure a collaborative approach to respond to humanitarian needs in Syria.

- Continue the discussion with donors around operational procedures and common standards for operations out of the Damascus hub, including agreed modalities for more effective risk sharing between humanitarian organizations and donors.

- Work between UN agencies and with INGOs in Damascus to improve and share conflict and risk analysis in programme design, and set out conflictsensitivity plans for all programmes conducted, whether or not they are part of the HRP.

- Ensure the centrality of protection in all programmes, including a focus on the reduction of gender-based violence, and that programmes meet Core Humanitarian Standards. 


\section{TO INTERNATIONAL NGOS WORKING FROM DAMASCUS}

- Improve and share conflict and risk analysis in programme design, ensuring that programmes Do No Harm and enhance protection of civilians.

- Ensure that programmes are designed bottom-up, with the involvement of the local community (including local government) to ensure that they meet the needs identified by conflict-affected populations, and increase accountability at the local level.

- When delivering early recovery and resilience programming, ensure that it does not reinforce a reduction in housing, land and property rights, and supports people's protection.

- Programmes should be designed through a gender lens, and livelihoods programmes should work with men to ensure that women can take up economic opportunities in all areas of the labour market, following a valuechain analysis and market assessment.

- Increase dialogue with local stakeholders to ensure that they are aware of humanitarian principles and have ownership over wider access to services. Undertake planning at an area-wide level.

- Ensure the centrality of protection in all programmes, including a focus on the reduction of gender-based violence. 


\section{NOTES}

1 Humanitarian Needs Overview (HNO), Syria, 2019.

https://reliefweb.int/sites/reliefweb.int/files/resources/2019 Syr HNO Full.pdf

2 However, the risks of asymmetric warfare or a resurgence of active armed conflict remain significant.

3 However, the risks of asymmetric warfare or a resurgence of active armed conflict remain significant.

4 The Global Cluster for Early Recovery. (2018). Deficit of peace in the humanitarian and development interface. https://reliefweb.int/report/world/deficit-peace-humanitarianand-development-interface

5 Meetings with programme partner organizations, Damascus, 10-14 February 2019.

6 This paper is based on Oxfam and DRC's programming inside Syria as well as discussions with programme partner organizations, technical line ministries, INGOs, UN and donor representatives in Damascus, Beirut and Amman in February 2019.

7 Oxfam Strategic Plan, 2013-2019. https://www.oxfam.org/sites/www.oxfam.org/files/oxfam-strategic-plan-2013-2019.pdf

8 Interview with INGO, Damascus, 17 February 2019.

9 Lessons Learned from the US experience in Afghanistan, John F. Sopko, Special Inspector General for Afghanistan Reconstruction, adapted from a speech delivered at Brookings on 24 May 2018. https://www.brookings.edu/blog/order-fromchaos/2018/05/30/lessons-learned-from-the-u-s-experience-in-afghanistan/

10 The Humanitarian Response Plan for Syria is made up of three components: 1 ) ensuring life-saving assistance reaches those most vulnerable; 2) ensuring the protection of civilians, reducing negative coping mechanisms and upholding International Humanitarian Law; and 3) increasing access to basic services and resilience among the population in need.

11 DRC has a longstanding presence in Damascus, having begun operations in 2008 and scaled up its response to the crisis in 2012. Access is negotiated under the terms of an established memorandum of understanding (MoU) with the Syrian Arab Red Crescent (SARC), and sub-MoUs with the Ministry of Education (MoE); Ministry of Local Administration and Environment (MoLAE); and Ministry of Social Affairs (MoSAL). All of our work is in line with humanitarian principles and takes a Do No Harm approach at all times.

12 Oxfam operates from Damascus, with a sub-office in Aleppo, under Memoranda of Understanding (MoUs) with the Ministry of Water Resources, Ministry of Agriculture and Agrarian Reform, Ministry of Social Affairs and Labor and the Ministry of Local Administration and Environment. Oxfam in Syria also works with three Syrian NGOs. All of our work is in line with humanitarian principles and takes a Do No Harm approach at all times.

13 HNO Syria 2019, op. cit.

14 Following UN Security Council Resolution 2165 (2014) and successor resolutions.

15 This is mainly, although not exclusively, limited to convoys as a result of high risks of aid diversion and fraud, combined with a challenging approval process.

16 While in theory the UNSC resolutions providing for cross-border aid still enable this modality to continue, in practice this has not been operationalized other than the movement of some supplies from Jordan into Syria. Syrian humanitarian workers have tended to stop their operations, fearing discrimination from the Government of Syria for working in areas under non-state-actor control.

17 This was still around $\$ 1 \mathrm{bn}$ short of what was requested. See Financial Tracking Service: https://fts.unocha.org/appeals/629/summary (accessed 26 February 2019).

18 Estimated by the Damascus INGO Forum, an informal platform that brings together 24 INGOs operating with an official registration with either the Government of Syria or another official body authorized by the Government of Syria.

19 Analysis by Damascus-based INGOs, September 2018. 
20 Oxfam internal paper on the nexus approach (2019), p. 10.

21 World Bank. (24 May 2016). The Importance of Planning Syria's Eventual Reconstruction. http://www.worldbank.org/en/news/feature/2016/05/24/theimportance-of-planning-syria-s-eventual-reconstruction

22 Scott Gates, Håvard Mokleiv Nygård and Esther Trappeniers. (2016). Conflict Recurrence, Conflict Trends, 2. Oslo: PRIO.

https://www.prio.org/Publications/Publication/?x=9056

23 World Bank. (3 March 2017). The Humanitarian-Development-Peace Initiative. http://www.worldbank.org/en/topic/fragilityconflictviolence/brief/the-humanitariandevelopment-peace-initiative

24 Good Humanitarian Donorship. 24 Principles and Good Practice of Humanitarian Donorship. https://www.ghdinitiative.org/ghd/gns/principles-good-practice-ofghd/principles-good-practice-ghd.html

252019 Syria Humanitarian Response Plan (HRP), forthcoming.

26 WHO and UNICEF Joint Monitoring Programme. (2017). Progress on Drinking Water, Sanitation and Hygiene: 2017 update and SDG baselines. Geneva: World Health Organization. www.washdata.org

27 Oxfam internal paper on WASH strategy, 2018.

28 Based on an exchange rate of $\$ 1=434$ SYP.

29 Cost of supply connection assumes $20 \%$ maintenance costs for the well in years 3,4 and 5 of its lifespan. The cost of private water trucking is not consistent, as it depends on the distance of the community from the water source and security factors. Eastern Ghouta provides a current working example.

30 Agenda for Humanity. https://agendaforhumanity.org/

${ }^{31}$ HNO Syria 2019, op. cit.

32 Oxfam internal paper on the nexus approach (2019).

33 Interview with INGO, Damascus, 17 February 2019.

34 Interview with UN Agency in Damascus, 11 February 2019

35 Discussion with INGO registered in Damascus, Amman, 8 February 2019.

36 Interview with INGO, Damascus, 17 February 2019.

37 Interview with INGO, Damascus,17 February 2019.

38 Workshops held by Syrian CSO, 2018.

392018 Syria HRP.

https://reliefweb.int/sites/reliefweb.int/files/resources/2018_2018_hrp_syria.pdf

40 The Centrality of Protection in Humanitarian Action, Inter-Agency Standing Committee, (2013).

https://interagencystandingcommittee.org/sites/default/files/the_centrality_of_protectio n_in_humanitarian_action_english_.pdf

41 HNO Syria 2019, op. cit.

42 Interview with UN agency, Damascus, 13 February 2019.

43 Interview with INGO, Damascus, 17 February 2018

44 UNFPA. Syrian women-headed households: hoping to survive and move on. https://reliefweb.int/sites/reliefweb.int/files/resources/UNFPA\%20Syrian\%20women\%20headed $\% 2$ households $\% 2$ C $\% 20$ hoping $\% 20$ to $\% 20$ survive $\% 20$ and $\% 20$ move $\% 20$ on.pdf

45 Legal aid assistance is currently only permitted by the Syria Trust and SARC, national organizations. 
46 The New Arab. (6 February 2019). East Aleppo flat evictions: A new ploy for ethnic cleansing? https://www.alaraby.co.uk/english/indepth/2019/2/6/aleppo-flat-evictions-anew-ploy-for-ethnic-cleansing-

47 These rules include the setting of a price, the right to appeal, and time limits for appeals to be heard.

48 Interview with INGO, Amman, 4 February 2019.

49 Meetings with programme partner organizations, Damascus, 10-14 February 2019.

50 Meetings with programme partner organizations, Damascus, 10-14 February 2019.

51 Interview with INGO, Damascus, 14 February 2019.

52 UN Agency in Damascus, 12 February 2019.

53 UN OCHA. (2012). What are Humanitarian Principles? https://www.unocha.org/sites/dms/Documents/OOMhumanitarianprinciples eng June12.pdf

54 Oxfam. (2013). Oxfam Policy Compendium Note: Oxfam's Role in Humanitarian Action. https://www.oxfam.org/sites/www.oxfam.org/files/hpn-role-humanitarianaction-010613-en.pdf

55 Omar Abdulaziz Hallaj, Who will own the cities? Urban Housing, Land and Property issues in Syria, Common Space Initiative, July 2017.

https://syrianechoes.com/2017/07/31/who-will-own-the-city-urban-housing-land-andproperty-issues-in-syria/

56 Interview with INGO, Damascus, 12 February 2019.

57 Discussion with INGO with registration in Damascus, Amman, 8 February 2019.

58 Filipa Schmitz Guinote. A Humanitarian-Development Nexus that works. June 2018, https://blogs.icrc.org/law-and-policy/2018/06/21/humanitarian-development-nexusthat-works/

59 Speech by Johannes Hahn, Commissioner for European Neighbourhood Policy and Enlargement Negotiations, on behalf of High Representative/Vice-President Federica Mogherini, at the plenary session of the European Parliament on the situation in Syria. https://eeas.europa.eu/delegations/kenya/58019/speech-johannes-hahncommissioner-european-neighbourhood-policy-and-enlargement-negotiations_kk (accessed 26 February).

60 EU Council Conclusions on the Integrated Approach to External Conflicts and Crises. (2018). https://ec.europa.eu/europeaid/sites/devco/files/2018-01cnl_conclusions_on_ia.pdf

61 The Global Cluster for Early Recovery. (2018). Deficit of peace, op. cit.

62 Stephen Heydemann. (2017). Rules for Reconstruction in Syria, op. cit.

63 Multiple interviews with INGOs, Amman and Damascus, 4-14 February 2019

64 Multiple interviews with UN agencies in Damascus, 10-14 February 2019

65 Interview with INGO, Amman, 4 February 2019.

66 Interview with donor, Beirut, 12 February 2019.

67 Good Humanitarian Donorship. 24 Principles and Good Practice, op. cit. 
(C) Oxfam International and Danish Refugee Council March 2019

This paper was written by Kathryn Achilles and Mathew Hemsley. Oxfam acknowledges the assistance of Sam Koplewicz in its production. It is part of a series of papers written to inform public debate on development and humanitarian policy issues.

For further information on the issues raised in this paper please email advocacy@oxfaminternational.org.

This publication is copyright but the text may be used free of charge for the purposes of advocacy, campaigning, education, and research, provided that the source is acknowledged in full. The copyright holder requests that all such use be registered with them for impact assessment purposes. For copying in any other circumstances, or for re-use in other publications, or for translation or adaptation, permission must be secured and a fee may be charged. Email policyandpractice@oxfam.org.uk.

The information in this publication is correct at the time of going to press.

Published by Danish Refugee Council and Oxfam GB for Oxfam International under ISBN 978-1-78748-419-1 in March 2019.

DOI: $10.21201 / 2019.4191$

Oxfam GB, Oxfam House, John Smith Drive, Cowley, Oxford, OX4 2JY, UK.

\section{OXFAM}

Oxfam is an international confederation of 19 organizations networked together in more than 90 countries, as part of a global movement for change, to build a future free from the injustice of poverty. Please write to any of the agencies for further information, or visit www.oxfam.org.

\section{DANISH REFUGEE COUNCIL}

The Danish Refugee Council (DRC) is a humanitarian, non-governmental, nonprofit organization founded in 1956 that works in 40 countries throughout the world. DRC fulfils its mandate by providing direct assistance to conflict-affected populations - refugees, internally displaced persons (IDPs) and host communities in the conflict areas of the world, and by advocating on their behalf internationally and in Denmark. 